\title{
Learning of Bullying's Acts Throught Social Learning
}

\section{Ph.D. Candidate Fitnet Hasekiu}

\author{
"Aleksander Xhuvani" University \\ Faculty of Educational Sciences \\ Psychology, Elbasan, Albania \\ e-mail: neta_hasekiu@yahoo.com
}

\section{Doi:10.5901/jesr.2013.v3n7p131}

\section{Abstract}

This scientific article is focused on the learning process of bullying's acts; especially on the learning of bullying's acts throught social learning (mainly by observation). From the analysed data in statistical way of the observations and the surveys conducted in two 9-year schools and two high schools in the city of Elbasan, it is found out that students more likely imitate the bullying's behaviors of their favourite students, of their parents or of the characters of different films. In this way, by adding those imitations some personal behavioral elements, they learn a new type of behavior. Many bullying's acts are learnt through observation. Observers in the case of bullying's acts are students and observational models include friends or classmates, parents, teachers, siblings, heroes of books, favourite sportsmen etc. From the analysed data in statistical way, it is also found out that the bullying's behaivors are especially repeated when the student sees that the model, whom he imitates, has received indirect reinforcements from his bullying's acts. Students can learn bullying's acts through observation of models, who perform bullying's acts. Students are more likely to learn through observation of bullying's acts performed by a model, who has been indirected reinforced as result of this bullying's acts.

Keywords: bullying's acts, social learning, reinforcement, indirect reinforcement, imitation, observation.

\section{Introduction}

Bullying is a widespread phenomenon of concern to many students school life. Psychological and physical consequences of bullying are numerous and long in time. These effects lead to poor performance of persons involved in bullying's acts in emotional, social, academic and other important areas. Consequences of bullying do not feel only in the school environment, but these consequences also move on to other social environment, which the students included in bullying's acts attend.

Although the phenomenon of bullying is a worrying phenomenon, the literature on this phenomenon in Albanian language is scarce. As a consequence of the nondisposition of scientific information about the phenomenon of bullying, school psychologists, teachers and parents in most cases do not give the appropriate importance on bullying's acts, and often even ignore them, which weighs heavily on emotional state of the students involved in bullying, especially in emotional well-being of victims of bullying's acts.

This scientific research is focused on the phenomenon of bullying, considering bullying's acts performed only among students in schools. Bullying is a complex phenomenon, but this research is especially focused on the learning of bullying's acts throught social learning (mainly by observation).

From frequently observations in school environments is noticed that many students are inclined to imitate behaviors, which are done before by other students, parents or characters of different movies. In this way, by adding to those imitations also some personal elements, they learn a new type of behavior. Many bullying's acts are learned through learning by observation. Learning by observation occurs when an observer's behavior is influenced by being witness to the model behavior (and often its consequences). Observers in the case of bullying are students and models include parents, teachers, siblings, schoolmates, heroes of books, sports etc.. In this scientific research is aimed to be prove this hypothesis: Students can learn bullying's acts by observing a model, which performs bullying's acts.

\section{Research methodology}

Population: The phenomenon of bullying is a widespread and concerned phenomenon primarily for students in secondary schools. Hence, the theoretical population of this empirical scientific research are: the students of secondary 
schools in the Municipality of Elbasan.

Sample: Total 600 students of four secondary schools, 150 students of school "Sule Harri", 150 students of school "Vasil Kamami", 150 students of school "Ahmet Dakli" and 150 students of school "Kostandin Kristoforidhi". Schools and students were selected in casual way in collaboration with the Regional Education Directorate.

Instruments: The instruments used in this scientific research are observation and surveys. But as the instrument which has the highest weight in this study to verify whether or not the hypothesis is the questionnaire. The used questionnaire is "Scale of bullying in school - Olweus", revised in collaboration with teachers and school psychologists of Elbasan, in order to make it more suitable for the purpose of this research. To assess the validity of these questions was conducted also the pre - test, which made it possible and necessary revision of some questions. The pre - test was conducted with 20 students, divided 10 male and 10 female, then not included in the survey, who where asked about understanding and clarity of responses before and after filling in the questionnaire. The final version of the questionnaire was complied, after being taken into consideration their opinions about understanding and clarity of the questions. The variables of the questionnaire are dichotimic in order to obtain clear and accurate results.

Procedure: The followed steps of the research are:

$>$ The development of the hypothesis.

$>$ The determination of the theoretical population on which the experiment was conducted.

$>$ The construction of the sample.

$>$ The realization of the pre- test in order to define the hypothesis on which the experiment was conducted.

$>$ The development of the final draft's version of the questionnare, in close cooperation with representatives of the Regional Education Directorate Elbasan and school psychologist.

$>$ Implementation of the questionnaire. For conducting this questionnare was taken the appropriate permit from the Regional Education Elbasan, as well as permission from the parents of the students surveyed, to whom was explained in detail what is bullying, goals, objectives and modalities of the survey in this research. Also they were insured for their children's anonymity and were asked not to talk with their children prior to the questionnare, so that they were not influenced in their responses from their parents. To the students were also taken their consent of filling in the questionnare. To them were also given the right information about bullying, were clarified any uncertainty about the questions and completing of the questionnaire procedure and they were assured that their data will remain confidential.

$>$ The selection of quetionnares evaluated as regular.

The data entry and their processing in SPSS programm.

$>$ The interpretation of the data.

\section{Analysis}

The statistical data presented in the graph below shows that $84.6 \%$ of the surveyed subjects claimed to have committed acts of bullying last 3-4 months in school. 15.4\% of them claimed to have done bullying's acts, upon seeing their friends, family or characters on television performing those acts. This shows that they have learned bullying's acts through observation and imitation of these acts.

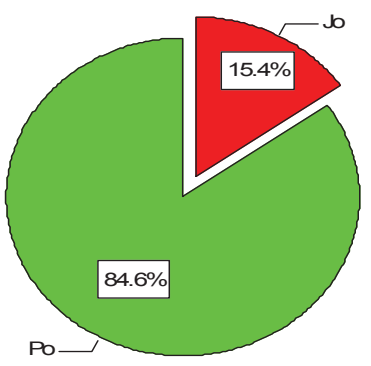




\section{Conclusions}

In educating children, the parents and the teachers have a difficult and demanding role. Like no other, they are responsible in ensuring that children develop emotionally, socially, and academically. The fact is that, like adults, in coping with today society's pressures and demands, children are paying a heavy emotional toll too. At alarming rates, more and more children and adolescents are experiencing all kinds of stress and trauma reactions, and at all levels of severity. Since children's affective and emotional status strongly influence how they perform in the classroom, it is imperative for teachers to become acquainted with how students develop and function socio-emotionally. Bullying is a widespread phenomenon of concern to many students school life. The parents, the teachers and the society itself should pay more attention on bullying's acts in order to prevent them. Bullying's acts could be learned by observing bullying models, so the children should not be exposed to such models. Even if it occures, to the children should be explained the bad consequences of those acts.

\section{References}

Baldry, A.C. (2003). Bullying in schools and exposure to domestic violence. Child Abuse \& Neglect, 27, 713-732.

Bandura, A. (1973). Aggression: A social learning analysis. Englewood Cliffs, NJ: Prentice-Hall.

Camodeca, M. \& Goossens, F.A. (2005). Aggression, social cognitions, anger and sadness in bullies and victims. Journal of Child Psychology \& Psychiatry, 46(2), 186-197.

Carney, A.G. \& Merrell, K.W. (2001). Bullying in schools: Perspective on understanding and preventing an international problem. School Psychology International, 22(3), 364-382.

Olweus, D. (1993). Victimization by peers: Antecedents and long-term outcomes. In K.H. Rubin \& J.B. Asendorpf (Eds.), Social withdrawaal, inhibition. and shyness in childhood (pp. 315-341). Hillsdale: Erlbaum.

Olweus, D. (1996). Gewalt in der Schule: Was Lehrer und Eltern wissen sollten - und tun können. Bern: Huber.

Perry, D.G., Kusel, S.J. \& Perry, L.C. (1988). Victims of peer aggression. Developmental Psychology, 24, 807-814.

Salmivalli, C., Lagerspetz, K., Björkqvist, K., Östermann, K. \& Kaukiainen, A. (1996). Bullying as a group process: Participant roles and their relations to social status. Aggressive Behavior, 22, 1-15. 